\title{
All to play for in Madrid
}

\section{London}

A controversial French and Australian proposal that would have made Antarctica a unique continental "natural reserve' was rejected by delegates from the Antarctic Treaty nations, meeting in Vina del Mar, Chile, over the past three weeks. But the central plank of the French and Australian idea, a permanent ban on mineral exploitation in the continent, remains a live issue that is set to divide the 39 Antarctic nations once more, when they meet to continue negotiations in Madrid next April.

National delegates and environmentalist groups agree that the Chile meeting made some progress towards a framework for environmental protection in Antarctica. Environmentalists had dreaded a complete breakdown of negotiations, as the present voluntary ban on prospecting may be lifted if treaty members are no longer working towards an agreement on mining.

After more than two weeks of impasse, a draft protocol on environmental protection was put together by Rolf Andersen, head of the Norwegian delegation. Specific environmental issues, including mining, will be dealt with in separate annexes to the protocol. Scientists worried that new provisions to assess the environmental impact of research will restrict their work (see Nature 348, 269; 22 November 1990), must now wait until the Madrid meeting, or later, before that annex is finalized.

Paul Bogart, from Greenpeace International, says that negotiations progressed "at a snail's pace, but at least the snail is moving in the right direction". Environmentalists are pleased that the Conven- tion on the Regulation of Antarctic Mineral Resource Activities (CRAMRA), which would have allowed mineral exploitation in the future if all treaty members agreed to it, has been superseded by the plan to address the issue in the new protocol

But other experts say the demise of CRAMRA may be bad for Antarctic environmental protection in the long run. Treaty members may agree a moratorium on mineral exploitation for 30 years or more as a compromise solution (practical difficulties in any case will preclude mining or oil exploration in the near future). But US officials say that some ground rules to control exploitation must be drawn up to prevent the free-for-all that might ensue when any moratorium expires.

Ron Naveen, from Oceanites, a US educational foundation which concentrates on marine and island environmental issues, believes that some of the "positive aspects" of CRAMRA should be used as the basis for a minerals annex to the new protocol. The need for consensus agreement before allowing mineral exploitation could be extended to prospecting, he says, to strengthen environmental protection.

This will require a more flexible approach than the entrenched positions that dominated in Chile. The rigid French and Australian support for a total mining ban was opposed implacably by Japan, which is poor in minerals reserves and is CRAMRA's strongest supporter. British officials, while less inflexible than the Japanese, still have strong reservations about a permanent mining ban

Peter Aldhous

\section{Global research centres open}

\section{London}

IMPERIAL College, London, and the University of Oxford are both launching new environmental research centres in the hope that the recent high profile given to environmental issues will win funding from industry.

Imperial's Global Environment Research Centre opens tomorrow (14 December), with six staff and about $£ 1$ million of start-up funds from the college. But director Iain Thornton wants to recruit ten postdoctoral researchers and set up Britain's largest environmental library, which will require $£ 12$ million over the next five years. Thornton is seeking donations from companies in Britain, North America and Japan.

The Imperial centre will carry out research into climate change, pollution and clean technology, and will also develop environmental policy. Director of policy John Gordon, a former diplomat, hopes to use seminars to bring together policymakers, industrialists and pressure groups. An independent voice is needed to ease the often confrontational relationship between government and environmentalist groups, he says.

Oxford's Environmental Change Unit will open in February, concentrating on the impact of environmental change on versity has again provided initial funding of more than $£ 1$ million, and the US computer company IBM has agreed to pay the director's salary and provide computing facilities. But another $£ 5$ million is still needed from industry.

Peter Aldhous forestry and natural ecosystems. The uni-

\section{France gets greener}

Paris

THE French National Assembly has approved a series of measures that will lead to the formation of a national environment institute and of a trio of government agencies with a brief to cut pollution and save energy.

The new environment institute, to be located at Cergy-Pontoise near Paris, will unite knowhow and data on environmental issues. According to the French environment minister Brice Lalonde, France has until now had a "do-it-yourself" system of expertise operating in each discipline. This has obscured a clear public image of environmental matters, and has been the source of "considerable distortion and financial waste".

France has only recently turned its mind to green matters, but is now acting with gusto. In the last budget, Lalonde was given a separate ministry, with a $\mathbf{4 0}$ per cent increase in funding. In June this year, he announced a more "aggressive" environment policy.

The French arm of the environmental group Greenpeace welcomes the initiatives, but is sceptical of their real impact. "It cannot do any harm", said a spokeswoman, "but it is more of a political facade designed to clear consciences."

Peter Coles

\section{STANFORD UNIVERSITY}

\section{Tacking on grants}

\section{San Francisco}

IN the latest episode of Stanford University's ongoing saga of problems with the high overhead rate it charges to government research grants, Stanford has admitted that in the name of research it billed taxpayers from 1981 to 1988 for depreciation of its 72-foot yacht, the Victoria, as well as for smaller sailboats, sculls and other equipment. The charges of $\$ 184,286$, which University officials attribute to an accounting error, have been repaid by reducing Stanford's claim for overhead expenses owed by the government, the University announced last week.

The charges came to light after queries by a US Congressional committee which is investigating university overhead rates, focusing on Stanford's 74 per cent addition to every research grant application. In October Stanford denied that any expenses related to the vessel were billed to the government. After additional probing by the General Accounting Office, however, the University said it had been mistaken and the yacht's depreciation, though not its operating costs, had been charged.

As Congressional inquiries continue, the Victoria, donated to Stanford in 1988 , remains anchored in the San Francisco Bay, where it is being offered for sale for $\$ 475,000$. 